\title{
INFLUENCE OF EFFECTIVE MICRO-ORGANISMS, SEAWEED EXTRACT AND AMINO ACIDS APPLICATION ON GROWTH, YIELD AND BUNCH QUALITY OF RED GLOBE GRAPEVINES
}

Sabry, Gehan H.; Mervat S. Rizk-Alla and M.A. Abd El-Wahab

Viticulture Dept., Hort. Res. Inst., Agric. Res. Center, Giza, Egypt

\begin{abstract}
This investigation was conducted for two successive seasons (2007 \& 2008) in a private vineyard located at El-Khatatba, Menoufiya governorate; to study the influence of effective micro-organisms, seaweed extract and amino acids application on growth, yield and bunch quality of Red Globe grapevines. The chosen vines were eight-year-old, grown in a sandy loam soil, spaced at $2 \times 3$ meters apart and irrigated by the drip irrigation system, cane-pruned and trellised by Spanish Parron system. Two rates of the conducted treatments were applied through soil drenching: effective microorganisms (EM) at 10 or $20 \mathrm{~cm} /$ vine; seaweed extract (Gifert) at 10 or 20 $\mathrm{cm} / \mathrm{vine}$ and amino acids (Pepton) at 0.5 or $1.0 \mathrm{~g} / \mathrm{vine}$ at three dates: the $1^{\mathrm{st}}$ date after bud burst stage, the $2^{\text {nd }}$ date after fruit set stage, and the $3^{\text {rd }}$ one at veraison stage.

Nine treatments were applied as follows:- Control (untreated vines); EM (10 cm/vine) (EM1); EM (20 cm/vine) (EM2); Gifert (10 cm/vine) (G1); Gifert (20 cm/vine) (G2); Pepton (0.5 g/vine) (P1); Pepton (1.0 g/vine) (P2);EM1 + G1 + P1 and EM2 + G2+ P2.

The results showed that the combined application of EM, Gifert and Pepton at the higher rate gave the best results in comparison with control followed by the lower rate of the same combined products. This treatment resulted in the best yield and its components as well as the best physical characteristics of bunches, improved physical and chemical characteristics of berries and ensured the best vegetative growth parameters. Total chlorophyll and percentages of total amino acids, nitrogen, phosphorus and potassium in the leaves and total carbohydrates in the canes were increased. With respect to microbiological activity in the rhizosphere, it was noticed that total spore forming; the populations of total microorganism; dehydrogenase and phosphatase enzymes activity increased in the rhizosphere as a result of the combined application of EM, Gifert and Pepton at the higher rate. On the other hand, control was found to record the minimum values of these characters.

The economical study indicated that the combined application of EM, Gifert and Pepton at the higher rate on Red Globe grapevines gave the highest net income as compared to the control.
\end{abstract}

\section{INTRODUCTION}

The use of biofertilizers, was suggested to be as one of the possibilities to restore the natural conditions. The mechanisms (by which microorganisms stimulate plant growth include biofertilization (increasing the supply of minerals such as N, P and $\mathrm{K}$ to the plants) and direct plant growth promotion by providing plants with hormones and vitamins (Lugtenberg et al., 1991). 
Microorganisms in the soil play a vital role in nutrients cycling and mediate various processes through their interactions with plants and other soil organisms. The importance of microorganisms (Fungi, bacteria, actinomycetes and yeast) can hardly be overstated. Yet their presence and activities are often disregarded in conventional agricultural systems, which rely heavily on non-sustainable inputs of energy, fertilizers and pesticides (Zarb et al., 1999).

Effective micro-organisms "known commercially as EM" is a mixed culture of beneficial microorganisms primarily photosynthetic and lactic acid bacteria, yeast, actinomycetes fermenting fungi that can be applied through the inoculation to increase the microbial diversity of the soil, this in turn can improve soil quality and fertility which enhance growth, yield and quality of crops (Higa and Kinjo, 1991).

Seaweed extract and its derivatives are used in agriculture as potential growth regulators. Biostimulant techniques using Seaweed extract are recommended for enhancing growth and fruiting of crops through producing amino acids, isopentenyl adenine-like substances, vitamin B12, Biotin and $\mathrm{GA}_{3}$ (Adam, 1999). Furthermore, Seaweed extract increases plant resistance to pests and diseases, improves plant growth, yield and fruit quality (Fornes, et al., 2002; El-Abbasy and El-Morsy 2002; Jensen, 2004 and Aisha et al., 2007).

Application of pure amino acids or compounds containing amino acids as yeasts (approximately 18 amino acids) (Abou-Zaid, 1984), proved to be favourable in enhancing growth, vine nutritional status, yield as well as physical and chemical characteristics of the berries in various grapevines cvs. (El-Mogy et al., (1998); Mansour 1998; Esmaeil et al., 2003 and Aisha et al., 2006).

One of the most promising new cultivars planted in Egypt is Red Globe: (late ripening seeded variety with colored berries). Quality of the clusters and berries is not rather good; since this cultivar is characterized by low vine vigour, which is reflected on increasing the possibility of berry exposure to sunburn damage besides the irregular colouration of the berry.

The aim of this investigation is to study the effect of Effective micro-organisms, Seaweed extract and amino acids on vegetative growth, yield and bunch quality of Red Globe grapevines.

\section{MATERIALS AND METHODS}

This investigation was conducted for two successive seasons (2007 \& 2008) in a private vineyard located at El-Khatatba, Menoufiya governorate; to study the influence of effective micro-organisms, seaweed extract and amino acids application on growth, yield and bunch quality of Red Globe grapevines. The chosen vines were eightyear-old, grown in a sandy loam soil (Table, 1), spaced at $2 \times 3$ meters apart and irrigated by the drip irrigation system, cane-pruned 
and trellised by Spanish Parron system. The vines were pruned during the third week of January with bud load of 72 buds/vine (6 canes X 12 buds/cane). One hundred thirty five uniform vines were chosen on the basis their growth depending on weight of prunings/vine and trunk diameter of the vine as indirect estimates for vine vigour. Each five vines acted as a replicate and each three replicates were treated by one of the following treatments.

Table (1): Physical, chemical and microbiological analysis of the soil

\begin{tabular}{|cl|c|}
\hline \multirow{5}{*}{ Physical } & Sand (\%) & 71.2 \\
\cline { 2 - 3 } & Silt (\%) & 2.1 \\
\cline { 2 - 3 } & Clay (\%) & 26.7 \\
\cline { 2 - 3 } & Texture & Sandy loam \\
\hline \multirow{5}{*}{ Chemical } & Organic carbon (\%) & 0.07 \\
\cline { 2 - 3 } & $\mathrm{pH}$ & 7.71 \\
\cline { 2 - 3 } & EC (Mmhos/cm) & 1.47 \\
\cline { 2 - 3 } & Water holding capacity (\%) & 24.0 \\
\cline { 2 - 3 } & Ca Co3 (\%) & 0.7 \\
\cline { 2 - 3 } & $\mathrm{N}(\%)$ & 0.92 \\
\cline { 2 - 3 } & $\mathrm{P}(\%)$ & 0.12 \\
\cline { 2 - 3 } Microbiological & 0.56 \\
\cline { 2 - 3 } & $\mathrm{K}(\%)$ & $9.7 \times 10^{5}$ \\
\cline { 2 - 3 } & Total spore forming (cfu/g soil) & \\
\cline { 2 - 3 } & Total microbial count (cfu/g soil) & \\
\hline
\end{tabular}

Effective micro-organisms were used under the trade mark (EM) which consists of a mixed culture of beneficial micro-organisms primarily photosynthetic and lactic acid bacteria, yeast and Streptomycetes.

Components of EM:

\begin{tabular}{|c|c|c|c|}
\hline Total bacterial & Lactic acid bacteria & Yeasts & Streptomycetes \\
\hline $2.5-9.6 \times 10^{4} \mathrm{cfu} / \mathrm{ml}$ & $6.6-9.9 \times 10^{6} \mathrm{cfu} / \mathrm{ml}$ & $10^{5}-10^{6} \mathrm{cfu} / \mathrm{ml}$ & $8.5 \times 10^{3} \mathrm{cfu} / \mathrm{ml}$ \\
\hline
\end{tabular}

Seaweed extract was used under the trade mark (Gifert) which is a modified ascophllum nodosum marine plant extraction composed of alginate, protein, fats, carbohydrates, marine salts and some trace elements (A.S.L., 2000).

Components of Gifert:

\begin{tabular}{|c|c|c|c|c|c|c|c|c|c|}
\hline Organic matter & $\mathbf{N}$ & $\mathbf{P}$ & $\mathbf{K}$ & $\mathbf{C a}$ & $\mathbf{M g}$ & $\mathbf{S}$ & $\mathbf{Z n}$ & $\mathbf{F e}$ & $\mathbf{M n}$ \\
\hline $45-60$ & 1.25 & 0.04 & 11 & 0.07 & $0.01-0.06$ & $0.1-0.5$ & $10-100$ & $50-200$ & $5-12$ \\
$\%$ & $\%$ & $\%$ & $\%$ & $\%$ & $\%$ & $\%$ & $\mathrm{ppm}$ & $\mathrm{ppm}$ & $\mathrm{ppm}$ \\
\hline
\end{tabular}

Amino acids were used under the trade mark (Pepton) which consists of some amino acids, organic nitrogen and potassium oxide.

\section{Components of Pepton:}

\begin{tabular}{|c|c|c|c|}
\hline Total amino acids & Free-L- amino acids & Organic N & K2O \\
\hline $85 \%$ & $16 \%$ & $12 \%$ & $4 \%$ \\
\hline
\end{tabular}




\section{Sabry, Gehan H. et al.}

Two rates of the conducted treatments were applied through soil drenching: effective micro-organisms (EM) at 10 or $20 \mathrm{~cm} / \mathrm{vine}$; seaweed extract (Gifert) at 10 or $20 \mathrm{~cm} / \mathrm{vine}$ and amino acids (Pepton) at 0.5 or $1.0 \mathrm{~g} / \mathrm{vine}$ at three dates: the $1^{\text {st }}$ date after bud burst stage, the $2^{\text {nd }}$ date after fruit set stage, and the $3^{\text {rd }}$ one at veraison stage.

Nine treatments were applied as follows:

1. Control (Untreated vines).

2. $\mathrm{EM}(10 \mathrm{~cm} / \mathrm{vine})(\mathrm{EM} 1)$.

3. $\mathrm{EM}(20 \mathrm{~cm} / \mathrm{vine})(\mathrm{EM} 2)$.

4. Gifert $(10 \mathrm{~cm} / \mathrm{vine})(\mathrm{G} 1)$.

5. Gifert $(20 \mathrm{~cm} / \mathrm{vine})(\mathrm{G} 2)$.

6. Pepton $(0.5 \mathrm{~g} / \mathrm{vine})(\mathrm{P} 1)$

7. Pepton (1.0 $\mathrm{g} / \mathrm{vine})(\mathrm{P} 2)$.

8. $\mathrm{EM} 1+\mathrm{G} 1+\mathrm{P} 1$.

9. $\mathrm{EM} 2+\mathrm{G} 2+\mathrm{P} 2$.

The following parameters were adopted to evaluate the tested treatments:-

A representative random sample of 6 bunches/vine were taken at maturity when TSS reached about $16-17 \%$ according to Tourky et al., (1995). The following characteristics were determined:

\section{Yield:}

Yield/vine $(\mathrm{kg})$ as number of bunches/vine $X$ average bunch weight $(\mathrm{g})$ were determined.

\section{Physical characteristics of bunches and berries:}

Average bunch weight $(\mathrm{g})$, average bunch length and width $(\mathrm{cm})$, average berry weight $(\mathrm{g})$, average berry size $\left(\mathrm{cm}^{3}\right)$ and average berry dimensions (length and diameter) $(\mathrm{cm})$ were determined.

\section{Chemical characteristics of berries:}

Total soluble solids in berry juice (T.S.S.) (\%) by hand refractometer and total titratable acidity as tartaric acid (\%) (A.O.A.C. 1985). Hence TSS /acid ratio was calculated. Total anthocyanin content of the berry skin was determined as $\mathrm{mg} / 100 \mathrm{~g}$ fresh weight according to Husia et al., (1965).

\section{Some characteristics of vegetative growth}

At growth cessation, the following morphological and chemical determinations were carried out on 4 shoots / the considered vine:

1 - Average shoot diameter $(\mathrm{cm})$.

2- Average shoot length $(\mathrm{cm})$.

3- Average number of leaves/shoot.

4- Average leaf area $\left(\mathrm{cm}^{2}\right)$ of the apical $5^{\text {th }}$ and $6^{\text {th }}$ leaves using a Cl-203Laser Area-meter made by CID, Inc., Vancouver, USA.

5-Total leaf area/vine $\left(\mathrm{m}^{2}\right)$ was determined by multiplying average number of leaves/shoot by average leaf area then by the number of shoots per vine.

6-Coefficient of wood ripening was calculated by dividing length of the ripened part of the shoot by the total length of the shoot according to Bouard (1966). 
7- Weight of prunings/vine in $(\mathrm{Kg})$ at dormancy period (winter pruning).

5. Chemical characteristics of vegetative growth

1- Leaf total chlorophyll content: this was measured by using nondestructive Minolta chlorophyll meter SPAD 502 (SPAD is an acronym for soil plant analysis development; Wood et al., 1992). It measures the relative amount of chlorophyll present by measuring the transmittance of the leaf in two wave bands 600700 and $400-500 \mathrm{~nm}$. The reading is proportional to the amount of chlorophyll.

2- Leaf total amino acid content (\%): this was determined according to Jayaraman, (1985).

3- Leaf mineral content: Nitrogen (\%) was determined using the modified micro-Kjeldahl method according to Pregl, (1945). Phosphorus (\%) was determined calorimetrically according to Snell and Snell (1967). Potassium (\%) was determined photometrically according to Jackson, (1967).

4- Cane total carbohydrate content (\%): this was determined according to Smith et al., (1956).

6. Microbiological studies:-

Samples of the soil were taken after harvest for carrying out the following determinations:

1-Total spore forming (-x $10^{5}$ colony forming unit (cfu)/g soil) according to (Massoud, 2005).

2-Total microbial count $\left(-\times 10^{5}\right.$ colony forming unit (cfu)/g soil) according to (Esher and Jensen 1972).

3-Dehydrogenase enzyme activity ( $\mu \mathrm{gTPF} / \mathrm{g} / \mathrm{D} . W$. soil/day) according to Salman (1967).

4-Phosphatase enzyme activity (IP/g/D.W.soil/day) according to Drobnikova (1961).

- Statistical analysis:

The complete randomized block design was adopted for the experiment. The statistical analysis of the present data was carried out according to Snedecor and Chocran (1980). Averages were compared using the new L.S.D. values at $5 \%$ level. Percentages were transformed by a certain equation prior to the statistical analysis.

\section{RESULTS AND DISCUSSION}

\section{Yield:}

Yield was significantly increased by the application of EM, Gifert and Pepton at the two rates either in the single or in the combined form (Table, 2). The combined application of EM, Gifert and Pepton at the higher rate resulted in the highest values of this estimate followed by the combined application of EM, Gifert and Pepton at the lower rate, whereas, the lowest values were given by the control. The beneficial effect of the applied treatments on the yield/vine could be ascribed mainly to the increase in bunch weight in the first season and the increase of number of bunches /vine beside the increase in bunch weight in the second season. 


\section{Sabry, Gehan H. et al.}

\section{2}

6622 
The positive effect of EM and Seaweed extract on the yield could be attributed to the enhancing effect on berry weight; in addition, EM contains primarily photosynthetic and lactic acid bacteria, yeast, actinomycetes fermenting fungi that can be applied through the inoculation to increase the microbial diversity of the soil, this in turn can improve soil quality and fertility which enhances the growth, yield and quality of crops (Higa and Kinjo, 1991). Seaweed extract contains macro and micro elements plus some organic compounds such as growth regulators (Senn and Kingman, 1978). This beside the effect of Seaweed extract on activating the synthesis of proteins and carbohydrates, also, Seaweed contains auxins, cytokinin and gibberellins which enhance cell division and enlargement resulting in an appreciable increment in berry weight and size.

The positive role of amino acids in increasing cell division and the biosynthesis of organic foods which is reflected on growth enhancement, vine nutritional status, number of clusters/vine, cluster weight could explain the increase in the yield/vine (Ahmed and Abd El-Hameed, 2003).

These results to the positive effect are in agreement with those found by Paschoal et al., (1999) who worked on EM; Ahmed, et al., (1997); Abada (2002) and Mahran (2005) who worked on the Seaweed extract; Esmaeil et al., (2003) and Aisha et al., (2006) who worked on the yeast as a source of amino acids.

\section{Physical characteristics of bunches and berries:}

Positive effects attributed to all applied treatments at the two rates either in the single or in the combined form were evident on physical characteristics of bunches and berries (Table, 2 and 3 ).

As for bunch weight, it was positively affected by the conducted treatments in a manner similar to that of the yield per vine.

Concerning bunch dimensions (bunch length and bunch width), the results revealed that positive effect of the treatments; all treatments of the two rates either in the single or in the combined form recorded significantly the highest values in comparison with control in both seasons. The combined application of EM, Gifert and Pepton at the higher rate resulted in the highest values of this estimate followed by the combined application of EM, Gifert and Pepton at the lower rate, whereas, the lowest values were obtained from control.

The positive influence of all applied treatments at the two rates either in the single or in the combined form were evident on physical characteristics of berries i.e. berry weight, size, length, diameter, except for the shape index which was insignificantly affected. The combined application of EM, Gifert and Pepton at the higher rate resulted in the highest values of this estimates followed by the combined application of EM, Gifert and Pepton at the lower rate, whereas, the lowest values were obtained from control.

The positive effect of EM on physical characteristics of bunches and berries may be due to that EM contains primarily photosynthetic and lactic acid bacteria, yeast, actinomycetes fermenting fungi that can be applied through the inoculation to increase the microbial diversity of the soil, this in turn can improve soil quality and fertility which enhances the growth, yield and quality of crops (Higa and Kinjo, 1991). 


\section{Sabry, Gehan H. et al.}

3

6624 
The promoting effect of Seaweed extract on physical characteristics bunches and of berries may be due to that encourages the uptake of various nutrients, activating photosynthesis process and cell enlargement (seaweed is considered as a source of cytokinin) (Blunden, 1977). In addition, the promoting effect of biofertilizers on the biosynthesis and translocation of carbohydrate is certainly reflected on improving berry quality (Abd ElHameed, 2005).

The positive role of amino acids in increasing cell division and biosynthesis of organic foods which is reflected on enhancing growth and improving vine nutritional status, could be responsible for improving physical characteristics of bunches and berries (Ahmed and Abd El-Hameed, 2003).

The obtained results in this respect are in accordance with those reported by Paschoal et al., (1999) who worked on EM; Ahmed, et al., (1997); Abada (2002) and Mahran (2005) who worked on the Seaweed extract; ElMogy et al., (1998), Esmaeil et al., (2003) and Aisha et al., (2006) who worked on the yeast applications as a source of amino acids.

\section{Chemical characteristics of berries:}

Data presented in (Table 4) revealed that all berry chemical characteristics; i.e. TSS, Acidity, TSS/acid ratio and anthocyanin content of berry skin were significantly affected by the application of EM, Gifert and Pepton at the two rates either in the single or in the combined form. The combined application of EM, Gifert and Pepton at the higher rate resulted in the highest values of TSS percentage, TSS/acid ratio, anthocyanin content in berry skin and the lowest acidity of the juice followed by the combined application of EM, Gifert and Pepton at the lower rate as compared to the control.

The favourable influence of Seaweed extract on chemical characteristics of berries may be ascribed to its simulative effect on photosynthesis process and its contain of some promoter hormones such as cytokinin which is closely involved in cell division, proteins, carbohydrates and chlorophylls (Featonby and Van Standen, 1984).

The positive effect of amino acids on berry chemical characteristics could be attributed to that amino acids play an important role in the biosynthesis and translocation of sugars and building of anthocyanin pigments (Ahmed and Abd El-Hameed, 2003).

The results in this connection are in line with those found by Paschoal et al., (1999) who worked on EM; Ahmed, et al., (1997); Abada (2002) and Mahran (2005) who worked on the Seaweed extract; El-Mogy et al., (1998), Esmaeil et al., (2003) and Aisha et al., (2006) who worked on the yeast as a source of amino acids.

\section{Some characteristics of vegetative growth}

Data in (Table 5) show that most of vegetative growth parameters (shoot diameter, shoot length, number of leaves per shoot, leaf area, total leaf area/vine, coefficient of wood ripening and weight of prunings) responded positively to all applied treatments at the two rates either in the single or in the combined form. 


\section{Sabry, Gehan H. et al.}

4

6626 
J. Agric. Sci. Mansoura Univ., 34 (6), June, 2009

5

6627 
The combined application of EM, Gifert and Pepton at the higher rate resulted in the highest values of these estimates followed by the combined application of EM, Gifert and Pepton at the lower rate. On the contras, the lowest values were obtained from control.

The favourable influence of EM on vegetative growth may be attributed to that EM contains primarily photosynthetic and lactic acid bacteria, yeast, actinomycetes fermenting fungi that can be applied through the inoculation to increase the microbial diversity of the soil, this in turn can improve soil quality and fertility which enhances growth, yield and quality of several crops (Higa and Kinjo, 1991).

The positive effect of Seaweed extract on vegetative growth can be ascribed to that Seaweed contains cytokinin (plant growth hormone) which is closely involved in cell division, proteins, carbohydrates and chlorophylls (Featonby and Van Standen, 1984). In addition, the stimulating effect of seaweed extract on vegetative growth might be due to its higher content of amino acids, cytokinins, vitamins $\mathrm{B}, \mathrm{GA}_{3}$ and mineral (Abou Zaid, 1984; Lugtenberg et al., 1991 and Adam, 1999).

The positive influence of amino acids on vegetative growth parameters could be explained in view of the important role played by these acids in enhancing the biosynthesis and movement of total carbohydrates as well as their positive action on stimulating both cell division and cell enlargement (Nijjar, 1985).

The results in this connection are in agreement with those found by Higa and Kinjo, (1991); Wibsono et al., (1996) and El-Kholy (2004) who worked on EM; Ahmed, et al., 1997 and Abada 2002 who worked on seaweed extract; El-Mogy et al., (1998), Esmaeil et al., (2003) and Aisha et al., (2006) who worked on the yeast as a source of amino acids.

\section{Chemical characteristics of vegetative growth}

All of the determined chemicals (expressed as total chlorophyll content, total amino acid content, percentages of total nitrogen, phosphorus and potassium of the leaves and total carbohydrate content of the canes \%) were positively affected by the applied treatments at the two rates either in the single or in the combined form. The highest significant effects over the control were due to the combined application of EM, Gifert and Pepton at the higher rate which gave the highest values of these estimates followed by the combined application of EM, Gifert and Pepton at the lower rate, whereas, the lowest values were obtained from the control (Table, 6).

The positive effect of EM on the nutritional status of the vines may be due to that EM contains selected species of microorganisms including predominant populations of lactic acid bacteria, yeast and smaller numbers of photosynthetic bacteria, actinomycetes and other types of microorganisms; which increased significantly the efficiency of the uptake of elements (Wibsono et al., 1996 and El-Kholy 2004).

The favourable influence of Seaweed extract on the nutritional status of the vines can be attributed to its content of different micro and macro nutrients (Aitken and Senn, 1965) which might have resulted in an increase in the uptake of elements. 
J. Agric. Sci. Mansoura Univ., 34 (6), June, 2009

6

6629 
In addition, the beneficial effect of Seaweed extract on the mineral content of leaves may be ascribed to the increase of root distribution and hence the uptake of elements is increased (Subba-Rao, 1984).

Amino acids increase cell division and biosynthesis of organic foods which are reflected on improving vine nutritional status (Ahmed and Abd ElHameed, 2003).

The results in this respect are in accordance with those found by Wibsono et al., (1996) and El-Kholy (2004) who worked on EM; Ahmed, et al., 1997 and Abada 2002 who worked on Seaweed extract; Esmaeil et al., (2003) and Aisha et al., (2006) who worked on the yeast as a source of amino acids.

Data illustrated in Figures $(1 \& 2 \& 3)$ indicated the existence of a highly positive correlation between total leaf area per vine $\left(\mathrm{m}^{2}\right)$ and yield $(\mathrm{kg})$, between total leaf area per vine (m2) and anthocyanin content of berry skin (mg/100g F.W.) and between total leaf area per vine $\left(\mathrm{m}^{2}\right)$ and cane total carbohydrates (\%) in both seasons.

\section{Microbiological studies:}

As far as total spore forming and total microbial count are concerned, it is obvious from the results presented in table (7) that all applied treatments at the two rates either in the single or in the combined form increased the populations of rhizospheric microorganisms in the roots. The highest significant effects over the control were due to the combined application of EM, Gifert and Pepton at the higher rate which resulted in the highest values of these estimates followed by the combined application of EM, Gifert and Pepton at the lower rate, whereas, the lowest values were given by the control.

The positive effect of EM on total spore forming and total microbial count may be due to that EM contain a large population of effective microorganisms, which could enhance the microbial diversity of the soil, this in turn can improve soil quality, fertility and soil bioactivity (Higa and Kinjo, 1991). As regards the favourable influence of Seaweed extract and amino acids on total spore forming and total microbial count, this may be due to that their soluble exudates improved the interaction with other soil microorganism such as $\mathrm{N}$-Fixers resulting in a greater microbial abundance in the soil (Godeas et al., 1999 and Turk et al., 2006).

As for the activity of dehydrogenase and phosphatase enzymes, data shown in table (7) revealed an appreciable increase in dehydrogenase and phosphatase enzymes activity in all treatments giving an indication of increasing microbial activity in the soil. The highest significant effects over the control were due to all the combined application of EM, Gifert and Pepton at the higher rate resulting in the highest values of these estimates followed by the combined application of EM, Gifert and Pepton at the lower rate, whereas, the lowest values were given by the control.

The increase in dehydrogenase and phosphatase enzymes activity may be attributed to the intense activity of microflora as a mixture of biomass than each individual one. The highest increase in microbial respiration was recorded with the mixture of microorganism in the soil (Massoud, 2005). 
J. Agric. Sci. Mansoura Univ., 34 (6), June, 2009

fig

6631 
Sabry, Gehan H. et al.

7

6632 
J. Agric. Sci. Mansoura Univ., 34 (6), June, 2009

8

6633 


\section{Economical justification/Feddan of the recommended treatment (EM2 + G2 + P2) as compared with control:}

It can be shown from the data presented in Table (8) that applying the combined application of EM, Gifert and Pepton at the higher rate gave the maximum net profit compared with the control in both seasons. The very slight raise in the cost of production/Feddan over control for this treatment is economically justified in view of the higher price of the yield obtained from this treatment.

From the obtained results, it can be concluded that the combined application of EM, Gifert and Pepton at the higher rate gave the optimum results for yield, bunch quality, vegetative growth, leaf content of total chlorophyll and cane content of total carbohydrates of Red Globe grapevines.

\section{REFERENCES}

Association of Official Agricultural Chemists (1985): Official Methods of analysis Published by A.O.A.C., Benjamin Franklin Station, Washington DC, USA.

A.S.L. (2000): Acadian sea plants limited. Product and technical information. Published by the A.S.L., 30 Brown Avenue, Dartmouth Nova Scotia, Canada [C.F. www.acadian-seaplants.com].

Abada, M.A.M. (2002): effect of yeast and some micronutrients on the yield and quality of Red Roomy grapevines. M.Sc. Thesis Fac. Agric., Minia Univ., Egypt.

Abd El-Hameed, H.M. (2005): Response of Red Roomy grapevines to algae extract, yeast and mono potassium phosphate fertilizer. Minia J. of Agric. Res. And Develop. (25): 5 pp 883-904.

Abou-Zaid, M. (1984): Biochemical studies on fooder yeast. Ph.D. Thesis, Fac. Agric. Cairo Univ., Egypt.

Adam, M.S. (1999): The promotive effect of the cyanobacterium Nostoc muscom on the growth of some crop plants. Acta, Microbiologica Polonica. 48(2): 163-171.

Ahmed, A.M. and Abd El-Hameed, H.M. (2003): Growth, uptake of some nutrients and productivity of Red Roomy vines as affected by spraying of some amino acids, Magnesium and boron. Minia J. of Agric. Res. And Develop. (23): 4 pp 649-666.

Ahmed, F.F.; A.M. Akl; F.M. El Morsy and M.A. Ragab (1997): The beneficial effects of biofertilizers on "Red Roomy" grapevines (Vitis vinifera L.). Ithe effect on growth and vine nutritional status. Annals Agric. Sci., Moshtohor. 35 (1): 489-495.

Aisha S.A. Gaser, Hanaa A. El-Helw and Abd El-Wahab, M.A. (2006): Effect of yeast doses and time of application on growth, yield and fruit quality of Flame Seedless grapevines. Egypt J. of Appl. Sci., 21 (8B): 661-681.

Aisha S.A. Gaser; Mohamed, M.A.A and Abd El-Ghany A.A. (2007): Influence of seaweed extract (Acadian), EDTA-calcium, Ascorbic acid preharvest application on Crimson Seedless table grape: 1- Maturation and Fruit Quality. Egypt. J. Agric. Res., 85(6): 111-134. 
Aitken, J. and T. Senn (1965): Seaweed products as fertilizer and soil conditioner. Botanica Marina 8, 144.

Blunden, G. (1977): Cytokinin activity of seaweed extract. Mari Natural chemistry products, 377 .

Bouard, J. (1966). Recherches physiologiques sur la vigne et en particulier pour l'aoutment des sarments. Thesis Sc. Nat Bordeaux-France. Pp.34.

Drobnikova, V. (1961): Factors influencing the determination of phosphatase in soil. Folia Microbial. 6: 260.

El-Abbasy, U.K. and A.A. El-Morsy (2002): Effect of preharvest application of Seaweed extract and naphthalene acetic acid on Thompson Seedless grape during cold storage. $2^{\text {nd }}$ Inter. Conf. Hort. Sci., 10-12 Sept., Kafr El-Sheikh, Tanta Univ., Egypt. 294-311.

El-Kholy, M.F. (2004): Mitigation of chemical fertilization used in banana crop by biofertilizers. M.Sc. Thesis, Enviro. Sc. Agric. Sci. Inst. Enviro. St. Res. Ain Shams Univ. Egypt.

El-Mogy, M.M.; Omar, A.H. and Gasser, A.S.A. (1998): Effect of yeast application on bud fertility, physical, chemical characteristics, vegetative growth and yield of "Thompson Seedless" grapevines. J. Agric. Sci. Mansoura Univ. 23 (8): 387-388.

Esher, H. and Jensen, V. (1972): Aerobic chemo-organotrophic bacteria of Danish beech forest, OIKOS, 23: 248-260.

Esmaeil, F.H.; M.T. Wahdan and A.F. El-Sheikh (2003): Response of "Thompson Seedless" and "Roumi Red" grape cultivars to foliar sprays with yeast extract and $\mathrm{GA}_{3}$. J. Agric. Sci. Mansoura Univ. 28 (8): 6321 6334.

Featonby, S.B. and Van Standen, J. (1984): Identification and seasonal variation of endogenous cytokinins in Ecklonia maxima Botanica Marina, $27,527$.

Fornes, F., M.P. Sanchez and J.L. Guardiola (2002): Effect of a seaweed extract on the productivity of "De Nules" Clementine mandarin and Navelina orange. Botanica Marina, (45): 486-489.

Godeas A.; Fracchia S.; Mujica M.T. and Ocampo J.A. (1999): Influence of soil impoverishment on the interaction between Glomus mosseae and saprobe fungi. Mycorrhiza 9:185-189.

Higa, T. and S. Kinjo (1991): Effect of lactic acid fermentation bacteria on plant growth and soil humus formation. Pp. 140-147. In: Parr. S.B. Hornick and C.E. Whitman (eds) Proc. $1^{\text {st }}$ Intl. Conf. on Kyusei Nature Farming Oct. 17-21, Khon Kaen. Thailand Pub USDA Washington, D.C.

Husia, C. L.; B. S. Luh and C. D. Chichester (1965): Anthocyanin in free stone peach. J. Food Science, 30: 5-12.

Jackson, M.L. (1967): Soil Chemical Analysis. Printice-Hall Inc. Englewood Cliffs-N.S.

Jayaraman (1985): Postharvest biological control. Wiley Eastern Limited New Delhi.

Jensen, E. (2004): Seaweed: Fact or Fancy? The organic Broadcaster, (12):3. 
Lugtenberg, B.J.J.; Weger, L.A.; Bennett, J.W. and Deweger, L.A. (1991): Microbial stimulation of plant growth and protection from disease. Current Opinion in Biotechnology 3:3, 457-464.

Mahran, M.K. (2005): Response of White Banaty grapevines to fertilization with organic and biofertilizers as well as spraying with Ascobin. Ph. D. Thesis Fac. Agric. Minia Univ. Egypt.

Mansour, A.E.M. (1998): Response of Anna Apples to some biofertilizers. Egypt. J. Hort. 25 (2): 241-251.

Massoud, O.N. (2005): Microbiological and chemical evaluation of compost and its application in organic farming. Ph. D. Thesis, department of botany, Faculty of Science, El-Menoufia, University.

Nijjar G.S. (1985): Nutrition of fruit trees. Published by Mrs. Msha Rajhumar for Kalvani Publishers, New Delhi, Pp. 10-270.

Paschoal, A.D.; Senanayake, Y.D.A. and Senanayake, U.R. (1999): Improved soil chemical and physical conditions and their relations to yield and fruit quality of organs in a field under Kyusei Nature Farming and EM technology in Brazil $5^{\text {th }}$ Int. Conf. on Kyusei Nature Farming Bankok, Theiland 23-26 Oct., 1996-1997, Pp. 175-181.

Pregl, F. (1945): Quantitative Organic Micro-Analysis. $4^{\text {th }}$ Ed J. and A. Churchill, Ltd., London.

Salman, A.C. (1967): Uber die mikrobiello aktivitat und ihr Beziehung Zu Fruchtbartkeits merknmalen. einiger acherboden under besonderer Berucksichtigurg der dehydrogenase akativitat (TTC-Reduktion). Diss Giesen, ph. D. Thesis, W. Germany.

Senn, T.L. and A.R. Kingman (1978): Seaweed research in crop production. Economic development Administration. U.S. Dep. Of commerce Technical Assistance Grant, project. 99-6-09329-2.

Smith, F., Gilles, M.A., Hamilton, J.K. and Gedess, P.A. (1956): Colorimetric methods for determination of sugar and related substances, Anal. Chem.28, 350.

Snedecor, G. W. and Cochran, W.G. (1980): Statistical Methods. $7^{\text {th }}$ ed., The lowa State Univ. Press. Ames. , lowa, U.S.A., pp. 593.

Snell, F.D. and Snell, C.T. (1967): Colorimeteric Method of Analysis. D. van Nestrant Company Inc., P. 551-552.

Subba-Rao, N.S. (1984): Biofertilizers in Agriculture. Oxford, IBH Company New Delhi. Pp. 69.

Tourky, M.N., El-Shahat, S.S. and Rizk, M. H. (1995): Effect of Dormex on fruit set, quality and storage life of Thompson Seedless grapes (Banati grapes) J. Agric. Sci., Mansoura Univ., 20 (12): 5139-5151.

Turk M.A.; Assaf T.A.; Hameed R.M. and AL-Tawha A.M. (2006): Significance of myccrohizae world journal of agricultural sciences. 2(1): $16-20$.

Wibsono, A.; T. Buwonowati and G.N. Wididana (1996): effect of effective microorganisms (EM4) on the growth of citrus medica. Pp. 87-91. In H.A.H. Sharifuddin and A.R. Anuar (eds) Proc. $3^{\text {rd }}$ Conf. on effective microorganisms (EM) Nov. 16-19, 1994, Thailand. 
Wood, C.W., Reeves, D.W. and Himelrick, D.G. (1992): Relationships between chlorophyll meter readings and leaf chlorophyll concentration. $\mathrm{N}$ status and crop yield. A review: Proc. Agro. Soc. N.Z. 23: 1-9.

Zarb, J.; C. Leifert and A. Litterick (1999): Opportunities and challenges for the use of microbial inoculants in agriculture practice. Proceedings of the $6^{\text {th }}$ International Conference on Kyusei Nature Farming 28-31-October, Pretoria, South Africa.

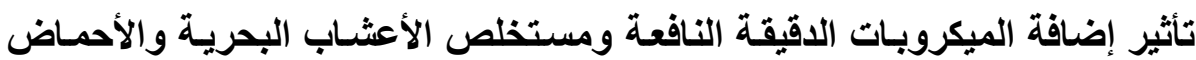

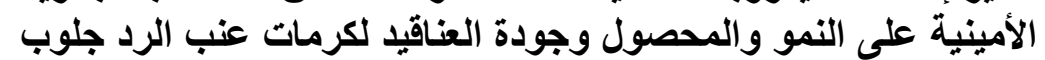

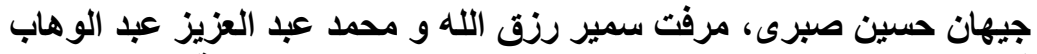

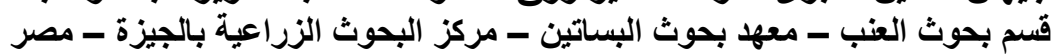

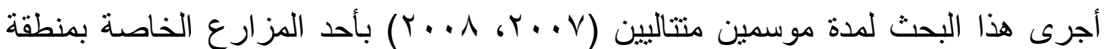

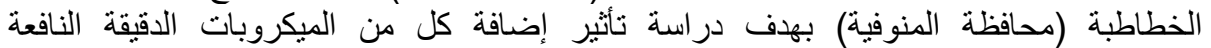

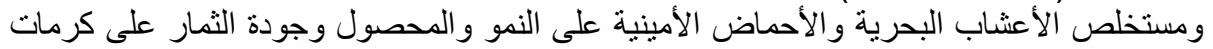

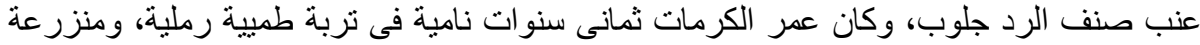

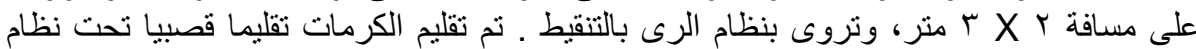

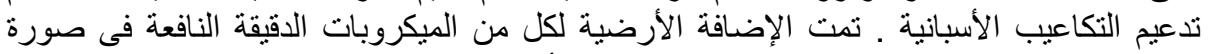

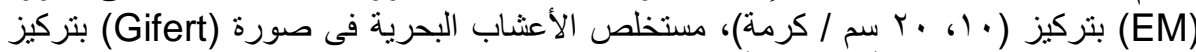

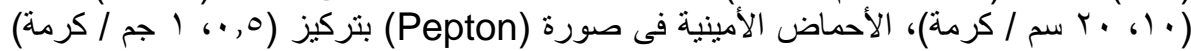

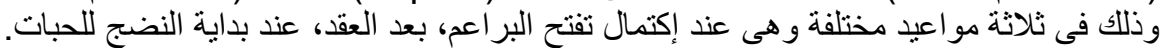

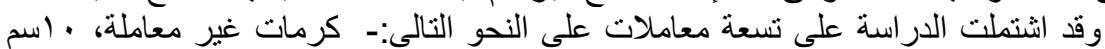

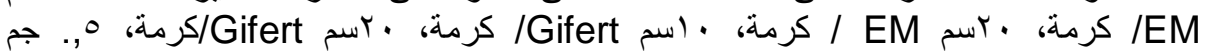

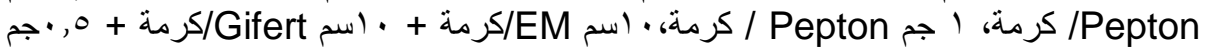

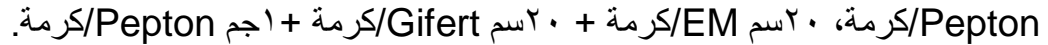

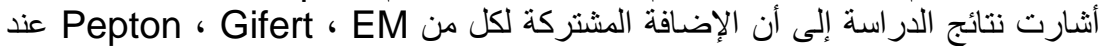

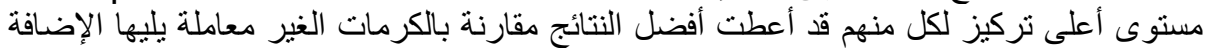

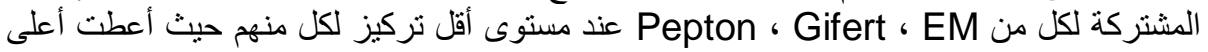

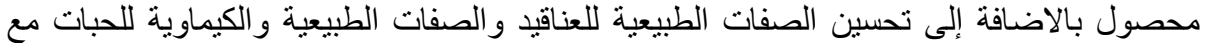

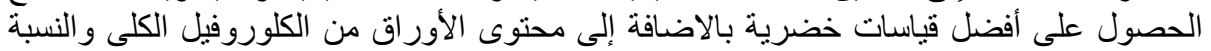

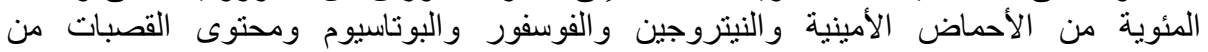

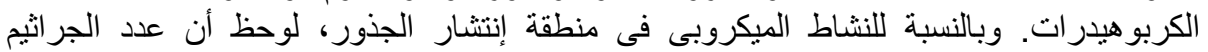

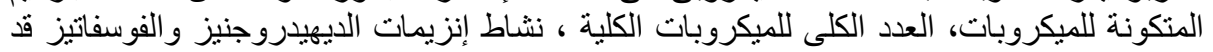

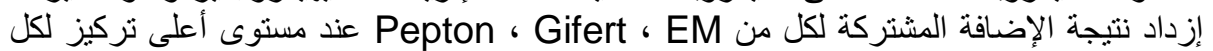

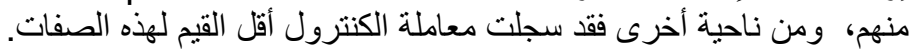

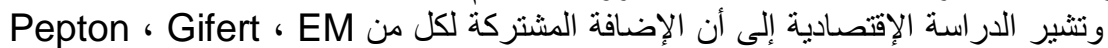

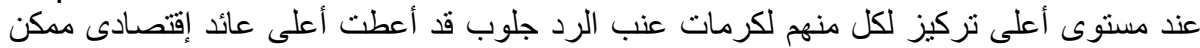

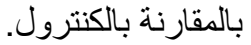

